\title{
Diatoms from lentic and lotic systems in Antioquia, Chocó and Santander Departments in Colombia
}

\author{
Silvia E. Sala ${ }^{1}$, John J. Ramírez ${ }^{2}$ \& Yasmín Plata ${ }^{3}$ \\ 1. Departamento Científico Ficología, Facultad de Ciencias Naturales y Museo, Paseo del Bosque s/n. 1900, La Plata, \\ Argentina; sesala@museo.fcnym.unlp.edu.ar \\ 2. Universidad de Antioquia, Instituto de Biología, Apartado 1226, Medellín, Colombia; johnra77@yahoo.com \\ 3. Grupo de Estudios en Biodiversidad, Departamento de Biología, Universidad Industrial de Santander, Apartado 678 \\ Bucaramanga, Colombia; yasplad@tux.uis.edu.co
}

Received 26-I-2007. C Corrected 30-VI-2008. Accepted 31-VII-2008.

\begin{abstract}
In the tropical and subtropical regions, there is a large number of species which has not been yet described. The high possibility of extinction makes their inventory a priority. In this paper, 23 diatoms taxa from Andean lotic systems and lentic waterbodies localized in the Departments of Antioquia, Santander and Chocó, Colombia, are analyzed with light and scanning electron microscopy. Each taxon is described and information about environmental characteristic of the sites where they were collected and distribution in Colombia is given. The studied taxa belong to the orders Thalassiosirales (1), Aulacoseirales (1), Fragilariales (4), Cymbellales (7), Achnanthales (2), Naviculales (7), and Thalassiophysales (1). Fifteen of them are recorded for the first time in Colombia and Encyonema jemtlandicum in South America. A comparison with the diatom flora of the Colombian Amazonia showed that there were only three taxa in common to these two equatorial regions probably due to the influence of altitudinal gradient. Rev. Biol. Trop. 56 (3): 1159-1178. Epub 2008 September 30.
\end{abstract}

Key words: diatoms, taxonomy, inland waters, tropics, Colombia, Andean region.

In the tropical and subtropical regions, there is a large number of species which has not been yet described. The high possibility of extinction makes their inventory a priority. Although most diatoms researchers work with the assumption that freshwater diatoms are widespread, the cosmopolitan paradigm is, however, in conflict with observations (Kociolek and Spaulding 2000). These authors pointed out that regional studies, in which a concerted effort to determine species with a consistent taxonomy, provide a way to examine cosmopolitism. They also mention several examples of morphological detailed studies which demonstrated that taxa may be misidentified or erroneously described as having disjoint distribution.

The information about the Diatom flora of South America is incomplete and needs a careful revision on the basis of modern tools. The most recent and general analyses of this flora were held by Metzeltin and Lange-Bertalot $(1998,2007)$ in tropical areas and by Rumrich et al. (2000) in the Andes from Venezuela to Tierra del Fuego. Metzeltin and Lange-Bertalot (1998) pointed out that in warm or cold regions of South America there is a great number of species that are cosmopolitan or typical of temperate climatic zones, while in the tropical regions the flora is completely different, with exception of the areas with a high anthropogenic influence, and that many endemic taxa were found. The observations of Rumrich et al. (2000) confirm these ideas with exception of many endemic taxa of high altitudes. These approaches are interesting as a start point of modern floristic studies in South America, but regional studies are still necessary for testing them because these analyses were based in a 
limited number of samples in relation to the dimensions of the studied area.

Colombia is an interesting country from a biogeographic point of view. The geographical situation favors the existence of a great variety of geomorphologic and climatic situations in small areas as a consequence of high altitudinal gradients. In this country, although there are numerous records of diatom taxa in ecological studies about periphitic communities (Moreno 1989, Donato et al. 1996, Montoya 1998), in paleoecological investigations (Lozano et al. 1999), and studies about phytoplankton ecology (Ramírez and Machado 1982, Ramírez 1994, Ramírez and Díaz 1994, Asprilla et al. 1998, Plata 2000, Ramírez et al. 2000, among many others), the knowledge about morphology and taxonomy of freshwaters diatoms is scarce. There are some publications about the Colombian Amazonia (Sala et al. 1999, 2002a, b) and descriptions of few species collected in high mountains (Lange-Bertalot and Moser 1994, Lange-Bertalot et al. 1996, Metzeltin and Lange-Bertalot 1998, 2007, Rumrich et al. 2000).

Ninety diatom taxa were identified in a preliminary study held in lentic and lotic systems from Antioquia and Chocó Departments, while 116 taxa were recorded in lotic systems of Santander Department. Approximately $30 \%$ of these taxa could not be assigned to recognized taxonomic entities being probably new for science. The aim of this paper is to describe those taxa common to these three systems, and to give information about the conditions in which they were collected and about their distribution in Colombia.

\section{MATERIALS AND METHODS}

Description of the study area: samples were collected from lotic and lentic systems of the Departments of Antioquia (05 $26^{\prime} 20^{\prime \prime}$ $\mathrm{N}-08^{\circ} 52^{\prime} 23^{\prime \prime} \mathrm{N}$; and $73^{\circ} 53^{\prime} 11^{\prime \prime} \mathrm{W}-77^{\circ} 07^{\prime} 16^{\prime \prime}$ W) and Santander $\left(05^{\circ} 42^{\prime} 34^{\prime \prime}\right.$ N-08 $07^{\circ} 58^{\prime \prime}$ N and $\left.72^{\circ} 26^{\prime} \mathrm{W}-74^{\circ} 32^{\prime} \mathrm{W}\right)$. These regions reflect many of the geographical characteristics of Colombia, because they belong to the Andean mountainous system. Also, samples from three shallow swamps were collected in the Department of Chocó ( $04^{\circ} 00^{\prime} 50^{\prime \prime} \mathrm{N}-08^{\circ} 41^{\prime} 32^{\prime \prime}$ $\mathrm{N}$ and $\left.76^{\circ} 02^{\prime} 57^{\prime \prime} \mathrm{W}-77^{\circ} 53^{\prime} 38^{\prime \prime} \mathrm{W}\right)$ that belongs to the region of the Pacific Plain.

La Vega Stream: la Vega is a small lotic system located between 790 and 1250 masl in the middle portion of the Nus River Basin (catchment area: $6.7 \mathrm{~km}^{2}$ ), Municipality of San José del Nus $\left(6^{\circ} 27^{\prime}\right.$ N-6 $6^{\circ} 29^{\prime} 30^{\prime \prime} \mathrm{N}$ and $74^{\circ} 49^{\prime} 30^{\prime \prime} \mathrm{W}-74^{\circ} 52^{\prime} \mathrm{W}$ ), Department of Antioquia. The studied material was collected in three sampling sites: Piedras Stream, Guaico Stream and La Vega Stream between August 2001 and April 2002. Two samplings were made during the rainy season (November 2001, April 2002) and two in the dry one (August 2001 and February 2002). The area is subject to tree felling and extensive cattle raising, with advanced erosion processes; the riparian vegetation is composed by grasses and short shrubs (Hernández-Atilano et al. 2005). Code samples: LPC10001, April 2002; LPC10002, February 2002; LPC10003, April 2002; LPC10004, April 2002; LPC10005, November 2001; and LPC10006, November 2002.

El Carmen de Viboral Municipality: this municipality $\left(6^{\circ} 05^{\prime} 09^{\prime \prime} \mathrm{N}, 75^{\circ} 20^{\prime} 19^{\prime}\right.$ 'W) is located on the Central Mountain Range of Los Andes to the west of the Department of Antioquia, has an extension of $448 \mathrm{~km}^{2}$, an altitude oscillating between 800 and 3340 masl. Its annual mean temperature is $17{ }^{\circ} \mathrm{C}$ and an annual mean precipitation oscillating between 2150 and $2235 \mathrm{~mm}$. In accordance to Espinal (1992) the Life Zone of this municipality is bh-MB (bosque húmedo-Montano Bajo). In this locality was sampled an artificial small lake, located at $6^{\circ} 4^{\prime} 51.6^{\prime \prime} \mathrm{N}, 75^{\circ} 20^{\prime} 7.8^{\prime \prime}$ $\mathrm{W}$. This lake has an elongated form, moderate slopes, a mean depth of $0.55 \mathrm{~m}$, a maximum depth of $2.80 \mathrm{~m}$ and its principal source is $\mathrm{La}$ Cuchilla spring. It is colonized by the floating macrophyte Nymphoides sp. (Montoya 2005). Code sample: LPC10011, November 2003.

Piedras Blancas Stream: it is a small stream located in the Park of the same name. Its basin is located between 2200 and 2600 masl 
on the Central Mountain Range of Los Andes, to the west of El Valle de Aburrá in the Department of Antioquia. It is an oblongousshaped basin, with a dendritic drainage pattern, with an annual mean precipitation of 1815 $\mathrm{mm}$, an annual mean temperature of $14.7^{\circ} \mathrm{C}$, a maximum of $20{ }^{\circ} \mathrm{C}$ and a minimum value of $5{ }^{\circ} \mathrm{C}$ (Empresas Públicas de Medellín 1988). It has two rainy periods (April- May and September- November).

In the basin there are two life zones -bh-MB (bosque húmedo Montano Bajo) and bmh-MB (bosque muy húmedo Montano Bajo)- with natural vegetation, plantations of pines, cypress, eucalyptus and others; a part used for pastures, cultures and tree nursery, among other use (Espinal 1992). Code sample: LPC10012, July 2003.

Tumaradó Swamp (7'30' N and $77^{\circ} 30^{\prime}$ $\mathrm{W}$ ): shallow waterbody (approximate $2-5 \mathrm{~m}$ depths) with black-type waters and a high content of humic substances incoming from the surrounding riparian wood. This swamp is located at the Parque Nacional Natural Los Katíos (PNNK), northwestern part of Colombia $\left(7^{\circ} 30^{\prime} \mathrm{N}, 77^{\circ} 30^{\prime} \mathrm{W}\right)$ in the border with Panamá at the zone of intertropical convergence. PNNK comprises $720 \mathrm{~km}^{2}$ belonging to the municipalities of Turbo (Department of Antioquia), Riosucio and Unguía (Department of Chocó) in the phytogeographic Province of Chocó. The dominant biome is the Tropical Rainy Forest. The park is located at an altitude varying between 2 and 650 masl with an annual precipitation varying from 2000 to $3500 \mathrm{~mm}$ and a mean annual temperature of $27^{\circ} \mathrm{C}$. Code samples: LPC10007, May 2000; LPC10008, May 2000; LPC10009, May 2000 and LPC10010, May 2000.

Lebrija River Basin: this river has a catchment area of $3727 \mathrm{~km}^{2}$, formed by 8 sub-basins and 25 micro-basins. The altitudinal gradient comprises from 300 to 3800 masl with mean temperatures of $30{ }^{\circ} \mathrm{C}$ to $6{ }^{\circ} \mathrm{C}$ and mean annual precipitation between 2065 and $660 \mathrm{~mm}$ respectively, with two rainy periods (March-May and September-November) and two dry periods (December-February and
June-August) (CDMB 2004). In the framework of study held to evaluate water quality of the basin, samples were collected in 25 sites, for this paper we choose those samples with greater species richness. These were collected at eight rivers, upstream and downstream of the polluted places and after the confluence of the rivers. Codes and some general characteristics of these places are given below.

El Salado Stream: 3250 masl, black waters and high transparency; mean depth 50 $\mathrm{cm}$; bed composed of small and median boulders; riparian vegetation composed by trees, dwarf bushes and grasses typical of paramuna vegetation. LPC10013, July 2000.

Vetas River before the confluence with Suratá River: 1600 masl Riparian vegetation composed by trees. Presence of dead leafs and signals of agriculture, cattle raising and sand extraction in the river bed. LPC10014, May 2000.

Suratá River before the water inlet to aqueduct of Bosconia: 720 masl; riparian vegetation predominantly composed by trees. LPC10015, May 2000.

Suratá River at the confluence with Oro River: 630 masl; strong influence of domestic, industrial and agricultural discharges. LPC10016, May 2000.

Frío River at the aqueduct of Floridablanca: 1060 masl; abundant riparian vegetation and domestic discharges upstream. LPC10017, March 2000.

Frío River before the treatment water plant of Girón: 780 masl; high anthropogenic influence, vegetation dominated by grasses; turbid waters and domestic solid residues. LPC10018, May 2000.

Oro River after the urban discharge of Piedecuesta: 840 masl; riparian vegetation with shrubs and grasses; solid residues. LPC10019, May 2000.

Lebrija River in front of the Vanegas municipality: 400 masl.; turbid water; in a wide valley with subsistence farming and cattle raising activities; woody riparian vegetation. LPC10020, June 2000. 
Methods: Epiliton samples at La Vega Stream were collected between August 2001 and April 2002 at three sampling places, brushing a total area of $900 \mathrm{~cm}^{2}$. At the Lebrija River Basin they were collected during May and July 2000 by brushing the surfaces of a variable number of substrates delimited with a $25 \mathrm{~cm}^{2}$ acrylic frame. At every place was also obtained information about water temperature, conductivity and dissolved oxygen. Fishes stomach contents samples from Tumaradó Swamps were obtained from Prochilodus magdalenae (Bocachico).

Samples were fixed with $10 \%$ Lugol or $6-8 \%$ formalin and were treated to eliminate organic matter following the method described in CEN/TC 230 (2002). Samples for light microscopy (LM) were mounted in Naphrax and for scanning electron microscopy (SEM) on glass stubs and then coated with gold-palladium in a Jeol FINE COAT ION SPUTTER JFC-1100. Observations were carried out with a Wild M20 LM and a Jeol JSM- T100 SEM at the Servicio de Microscopía Electrónica del Museo de La Plata.

Terminology used is that suggested in Anonymous (1975), Ross et al. (1979) and Barber and Haworth (1981).

The descriptions are accompanied with information about the physical and chemical data of the sites were the materials were collected. Information about distribution in Colombia is based in Imani (2003) and papers published afterwards.

Uncleaned and cleaned subsamples and permanent slides are deposited at the Laboratorio de Limnología del Instituto de Biología de la Universidad de Antioquia (Medellín, Colombia), the Colección Limnológica del Museo de Historia Natural de la Universidad Industrial de Santander (UIS) and at the Herbario of Departamento Científico Ficología, Museo de Ciencias Naturales de La Plata, Argentina (LPC).

\section{RESULTS}

\section{Achnanthidium minutissimum \\ (Kützing) Czarnecki (Fig. 1A, B)}

Czarnecki 1994, Mem. Calif. Acad. Sci. 17: 157.

Bas.: Achnanthes minutissima Kützing

Valves elliptical-lanceolate with rounded ends, sometimes slightly capitated. Raphe valve (RV): central area asymmetric reaching one margin. Axial area narrow, slightly widen to the valve center. Raphe filiform, external proximal ends gently dilated and internal ones slightly curved to opposite sides; distal ends externally curved to the same side and internally to opposite sides with little helictoglossae. Raphe-less valve (RLV): central area symmetric reaching both valve margins and axial area linear-lanceolate. Striae uniseriate, slightly radiate and interrupted near the mantle in both valves. Length: $8.5-23.0 \mu \mathrm{m}$; width: $2.5-3.0$ $\mu \mathrm{m}$; striae: $25-29$ in $10 \mu \mathrm{m}(\mathrm{RV})$; $25-26$ in 10 $\mu \mathrm{m}$ (RLV); areolae: 31-62 in $10 \mu \mathrm{m}$.

Studied material: LPC 10011, 10013, 10014.

Ecological data: altitude: 1600-3250 masl.; conductivity: $23-189 \mu \mathrm{Scm}^{-1}$; $\mathrm{T}^{\mathrm{o}} \mathrm{W}$ : $11.0-$ $26.3^{\circ} \mathrm{C}$; $\mathrm{pH}$ : 6.3-7.9; dissolved oxygen: 6.6-8.5 $\mathrm{mgl}^{-1}$.

Distribution in Colombia: this cosmopolitan species was mentioned in Alta Montaña Province (Donato, 2001).

\section{Amphora montana \\ Krasske (Fig. 2)}

Krasske 1932, Hedwigia 72: 119, Fig. 2.

Valves with the dorsal margin convex and with the ventral margin strongly tumid. Ends subcapitate, bent to the ventral side. Raphe forming an obtuse angle, close to the ventral edge; central external raphe endings slightly curved to the dorsal side and terminal ones 
dorsally deflected. Conopeum narrow; central area asymmetric, wider on the ventral side. Striae uniseriate, well developed at both sides, radiate at the center and convergent to the poles. Length: 14.5-16.0 $\mu \mathrm{m}$; width: 3.0-3.5 $\mu \mathrm{m}$. Dorsal striae: $37-44$ in $10 \mu \mathrm{m}$, ventral striae: 48 in $10 \mu \mathrm{m}$.

Studied material: LPC 10011, 10016.

Ecological data: altitude: 630-1 100 masl.; conductivity: $61.2-256.0 \mu \mathrm{Scm}^{-1} ; \mathrm{T}^{\mathrm{o}} \mathrm{w}: 23.2-$ $26.3{ }^{\circ} \mathrm{C}$; $\mathrm{pH}$ : 6.0-9.2; dissolved oxygen: 5.5-8.0 $\mathrm{mgl}^{-1}$.

Distribution in Colombia: this cosmopolitan species is recorded for the first time.

\section{Aulacoseira granulata}

(Ehrenberg) Simonsen (Fig. 3)

Simonsen 1979, Bacill. 2: 58

Bas.: Gallionella granulata Ehrenberg

Frustules rectangular in girdle view joined forming filiform colonies. The terminal and intermediate cells of the colony are morphologically different. Separating cells (terminal), with a ring of short spines and 1-2 long spines. Linking cells (intermediate), have short spines variable in morphology, in the same number as the areolae. Valve face smooth, in the linking cells, and with small areolae near the margin in the separating cells. Valve mantle high, with subcuadrangular to round areolae, arranged in straight lines in the separating valves, and slightly helicoidal in the linking cells. Collum narrow, with small knobs in some specimens. Ringleseite narrow. Diameter: 7-17 $\mu \mathrm{m}$; mantle height: 7.5-26.5 $\mu \mathrm{m}$; striae: 7-21 in $10 \mu \mathrm{m}$; areolae: $8-17$ in $10 \mu \mathrm{m}$

Studied material: LPC 10019, 10007.

Ecological data: altitude: 60-1 100 masl.; conductivity: $168-172 \mu \mathrm{Scm}^{-1} ; \mathrm{T}^{\circ} \mathrm{w}: 23-27^{\circ} \mathrm{C}$; pH: 5.8-7.2; dissolved oxygen: 4.7-5.3 $\mathrm{mgl}^{-1}$.

Distribution in Colombia: this cosmopolitan species was reported in Colombia at Provincias Andina, Tierras Bajas and Amazonia.

\author{
Caloneis aff. bacillum \\ (Grunow) Cleve (Fig. 4A, B)
}

Cleve 1894, Kongl. Svenksa Vetensk. Akad. Handl. 26(2): 99.

Bas.: Stauroneis bacillum Grunow

Valve linear to linear-lanceolate with rounded ends. Axial area narrow at the first third of the valve, widening to the valve center. Central area reaching both margins. Striae parallel to slightly radiate, irregular in length; areolae difficult to see even with SEM. Raphe filiform arched; external proximal ends dilated and slightly curved to the same side; terminal fissures curved in the same direction (opposite to the proximal ends). Length: $23-27 \mu \mathrm{m}$, width: 5.5-7.0 $\mu \mathrm{m}$; striae: $17-23$ in $10 \mu \mathrm{m}$.

Studied material: LPC 10011, 10019, 10015.

Ecological data: altitude: 720-1 100 masl.; conductivity: $61.2-190.0 \mu \mathrm{Scm}^{-1} ; \mathrm{T}^{\mathrm{o}} \mathrm{w}$ : 18.0-26.3 ${ }^{\circ} \mathrm{C}$; pH: 5.5- 8.6; dissolved oxygen: 4.7- $8.9 \mathrm{mgl}^{-1}$.

Distribution in Colombia: this cosmopolitan species is recorded for the first time.

Observations: Germain (1981) and Krammer and Lange-Bertalot (1986) described the species as extremely variable in valve outline and in the axial area. The studied materials differ from the materials described by these authors in the axial area and width of the central area, and coincide with the specimens illustrated in Rumrich et al. (2000) as Caloneis sp. cf. bacillum (Plate 136, Fig. 5, 6, 9).

\section{Cocconeis placentula var. euglypta}

(Ehrenberg) Grunow (Fig. 5-6)

Grunow 1884, Akad. der Wissenchaften, Bd. 48: 97

Bas.: Cocconeis euglypta Ehrenberg.

Valves elliptical to linear-elliptical. Raphe valve: axial area very narrow; central area small, more o less oval. Striae radiate, uniseriate, composed of a row of round are- 

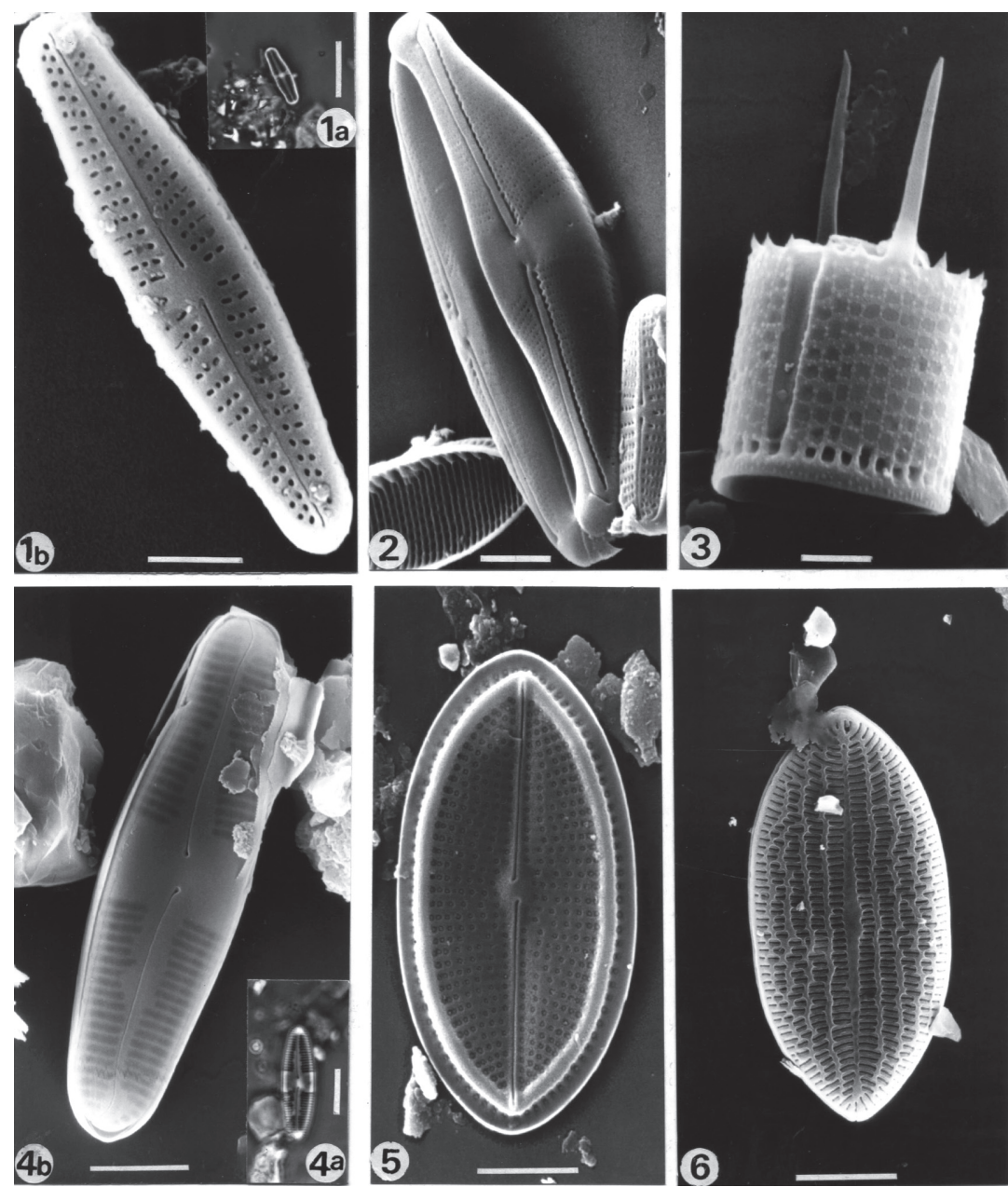

Fig. 1: Achnanthidium minutissimum, Fig. 1A: LM, valve view, Fig. 1B: SEM; raphe-valve in external view. Fig. 2: Amphora montana, SEM, complete frustule. Fig. 3: Aulacoseira granulata, SEM, terminal valve in external view. Fig. 4: Caloneis bacillum, Fig. 4A: LM, valve, Fig. 4B: SEM, valve in external view. Fig. 5, 6: Cocconeis placentula var. euglypta SEM, Fig. 5: raphe-valve in internal view, Fig. 6: rapheless-valve in external view. Scale bars $=2 \mu \mathrm{m}($ Fig. $1 \mathrm{~B}, 2-3), 6 \mu \mathrm{m}$ (Fig. 4B, 5, 6) and $10 \mu \mathrm{m}$ (Fig. 1A, 4A).

olae, interrupted at the valve margin by an internal circumferential costa. Raphe filiform with external proximal ends slightly dilated and distal ones straight and ended at the marginal hyaline costa. Internal proximal ends gently curved to opposite sides and terminal ones, straight, ended at small helictoglossae. Raphe-less valve: striae composed of 2-4 (5) areolae separated by longitudinal hyaline lines. Axial area narrow slightly widened at valve center; central area absent. Length:
19.5-26.0 $\mu \mathrm{m}$, width: 9.0-12.5 $\mu \mathrm{m}$; striae: $18-20$ in $10 \mu \mathrm{m}$ (raphe valve), 16-19 in $10 \mu \mathrm{m}$ (raphe-less valve).

Studied material: LPC 10002, 10003.

Ecological data: altitude: 630-1 100 masl.; conductivity: 126.2-256.0 $\mu \mathrm{Scm}^{-1}$; $\mathrm{T}^{\mathrm{o}} \mathrm{w}$ : $23-24{ }^{\circ} \mathrm{C}$; $\mathrm{pH}$ 6.0-9.2; dissolved oxygen: 5.5-8.8 $\mathrm{mgl}^{-1}$.

Distribution in Colombia: this cosmopolitan variety was mentioned in the Provincia de Alta Montaña. 


\section{Cyclotella meneghiniana}

Kützing (Fig. 7-8)

Kützing 1844, Die. Kiesel. Bacil. oder. Diat.: 50, Pl. 30, Fig. 68.

Cells drum shaped, solitary. Valve face with two differentiated areas, the central one tangentially undulated, with irregular areolae that do not penetrate the siliceous wall and the external one with areolae arranged in multiseriate fascicles and internal chambers. Fultoportulae with three satellite pores, 1-2 eccentric and the others in a marginal ring located at every interfascicle a little below the valve face/ mantle junction. One rimoportula placed in the same position of the fultoportulae ring. Valve mantle with strong spines placed at the valve face/ mantle junction and others small with variable distribution. Diameter: 10-18 $\mu \mathrm{m}$; fascicles: $6-8$ in $10 \mu \mathrm{m}$.

Studied material: LPC 10001, 10006.

Ecological data: altitude: 840-1 100 masl; conductivity: $168-172 \mu \mathrm{Scm}^{-1} ; \mathrm{T}^{\mathrm{o}} \mathrm{w}: 23-27^{\circ} \mathrm{C}$; pH: 5.8-7.2; dissolved oxygen: 4.7-5.3 $\mathrm{mgl}^{-1}$.

Distribution in Colombia: this species, mentioned in the literature as cosmopolitan, was recorded in the Provincia Andina and in the Provincia Costera.

\section{Cymbella affinis \\ Kützing (Fig. 9-11)}

Kützing 1844, Die. Kiesel. Bacil. oder. Diat.: 8, P1.6; Fig. 15.

Valves semilanceolate with subrostrate ends, dorsal margin strongly convex and ventral margin straight or slightly convex. Axial area narrow; central area slightly differentiated, with one stigma located at the end of the ventral median striae. Raphe complex, externally it is strongly undulated with proximal and distant ends curved to the dorsal side. Internally, the raphe is arched to the dorsal side of the valve, without intermissio and conspicuous helictoglossae. Striae uniseriate, radiate. Length: 40-48 $\mu \mathrm{m}$; width: $12-14 \mu \mathrm{m}$; dorsal striae: $7-10$ in $10 \mu \mathrm{m}$ at the center and 9-12 in $10 \mu \mathrm{m}$ at the poles; ventral striae: $8-10$ in $10 \mu \mathrm{m}$ at the center and 9-12 in $10 \mu \mathrm{m}$ at the poles; areolae: $25-26$ in $10 \mu \mathrm{m}$.

Studied material: LPC 10001, 10002, 10003, 10019.

Ecological data: altitude: 400-1 100 masl.; conductivity: $61.2-176.0 \mu \mathrm{Scm}^{-1}$; $\mathrm{T}^{\mathrm{o}} \mathrm{w}$ : 23.2-30.0 ${ }^{\circ} \mathrm{C}$; $\mathrm{pH}$ : 6.5-7.6; dissolved oxygen: 6.5-8.0 $\mathrm{mgl}^{-1}$.

Distribution in Colombia: this cosmopolitan species is registered for the first time in the country.

\section{Diadesmis confervacea \\ Kützing (Fig. 12 A, B)}

Kützing 1844, Bacill.: 109, pl. 30, Fig. 8.

Valves elliptical-lanceolate, joined forming band colonies. Axial area narrow at the poles widening to the valve center. At the valve face/mantle junction there is a row of small spines. Raphe filiform, straight, external distal ends slightly dilated and proximal ends expanded. Uniseriate striae, radiate, composed of few transapically elongated to circular areolae. Length: 20.5-22.0 $\mu \mathrm{m}$, width: 6.5-8.5 $\mu \mathrm{m}$; striae: $16-20$ in $10 \mu \mathrm{m}$ at the center and $22-24$ in $10 \mu \mathrm{m}$ at the ends; areolae: 14 in $10 \mu \mathrm{m}$.

Studied material: LPC 10006, 10020.

Ecological data: altitude: 400-1 100 masl.; conductivity: $61.2-176.0 \mu \mathrm{Scm}^{-1} ; \mathrm{T}^{\mathrm{o}} \mathrm{W}$ : 23.2-30.0 ${ }^{\circ} \mathrm{C}$; $\mathrm{pH}$ : 6.5-7.4; dissolved oxygen: 6.5-8.0 $\mathrm{mgl}^{-1}$.

Distribution in Colombia: this taxon was also found in Amazonia.

\section{Encyonema jemtlandicum \\ Krammer (Fig. 13, 14, 16)}

Krammer 1997, Bibl. Diat. 36: 82, Fig. 35: 1-9.

Valves semilanceolate, dorsal margin convex, and ventral margin slightly tumid, apices acute not differentiated. Axial area narrow, slightly dilated at the central area. Raphe complex, externally the raphe branches are strongly sinuous, with proximal ends dilated and curved to the dorsal side and terminal ends curved to the ventral side and internally straight with 

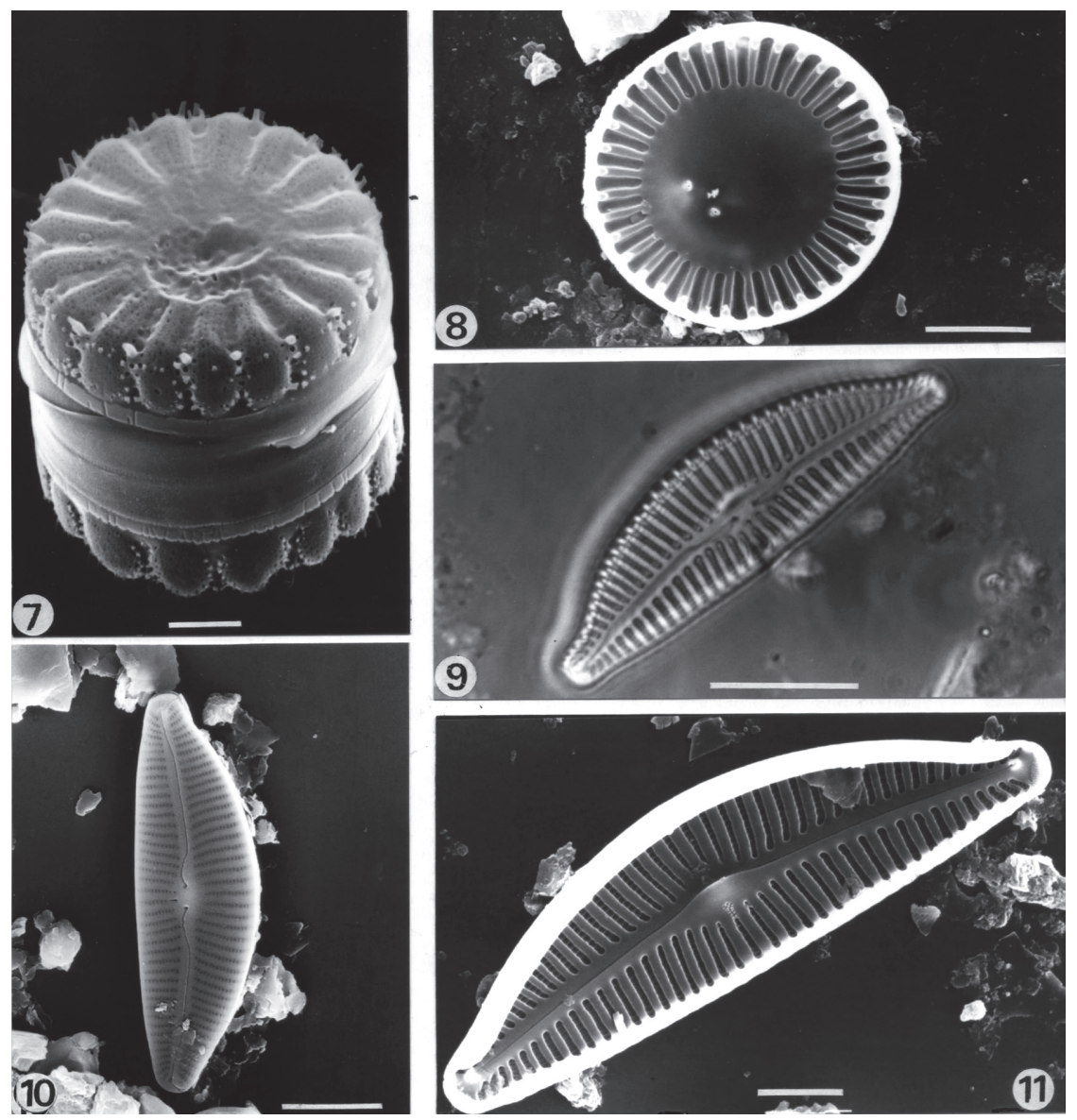

Fig. 7-8: Cyclotella meneghiniana SEM: Fig. 7: complete frustule; Fig. 8: valve in internal view. Fig. 9-11: Cymbella affinis, Fig. 9: LM, valve, Fig. 10: SEM, valve in external view, Fig. 11: SEM, valve in internal view. Scale bars=2 $\mu \mathrm{m}$ (Fig. 7 ); 5 $\mu \mathrm{m}$ (Fig. 11); $6 \mu \mathrm{m}$ (Fig. 8); $10 \mu \mathrm{m}$ (Fig. 10) and $15 \mu \mathrm{m}$ (Fig. 9).

proximal ends curved to the dorsal side in straight angles and terminal ones not reaching the poles. Dorsal striae radiate and ventral striae parallel at the center and convergent at the poles; interstriae wide. Length: $34-35 \mu \mathrm{m}$, width: $7.5 \mu \mathrm{m}$; dorsal striae: 10 in $10 \mu \mathrm{m}$; ventral striae: 11 in $10 \mu \mathrm{m}$; areolae: 33 in $10 \mu \mathrm{m}$.

Studied material: LPC 10007.

Ecological data: altitude: 60 masl; conductivity: $172 \mu \mathrm{S} . \mathrm{cm}^{-1} ; \mathrm{T}^{\mathrm{o}} \mathrm{w}: 27 ; \mathrm{pH}: 7.20$; dissolved oxygen: $5.8 \mathrm{mgl}^{-1}$.

Distribution in Colombia: this taxon has been reported by Krammer (1997) only for Döda fallet; Abisko, Schwedisch-Lappland. In Colombia it is registered for the first time.
Observations: the studied material coincides with the specimens described in Krammer (1997: 166, Fig. 35).

\section{Encyonema aff. jemtlandicum var. venezolana Krammer (Fig. 15)}

Krammer 1997, Bibl. Diat. 36: 82, Fig. 14: 1-5, 36: 1-3.

The studied material differs from the var. jentlandicum in the narrower interstriae, the dorsal areolae near the raphe more distant than the others, and the external proximal ends less dilated. Length: $35 \mu \mathrm{m}$, width: $8 \mu \mathrm{m}$; dorsal striae: 11 in $10 \mu \mathrm{m}$ (center), 12 in $10 \mu \mathrm{m}$ 

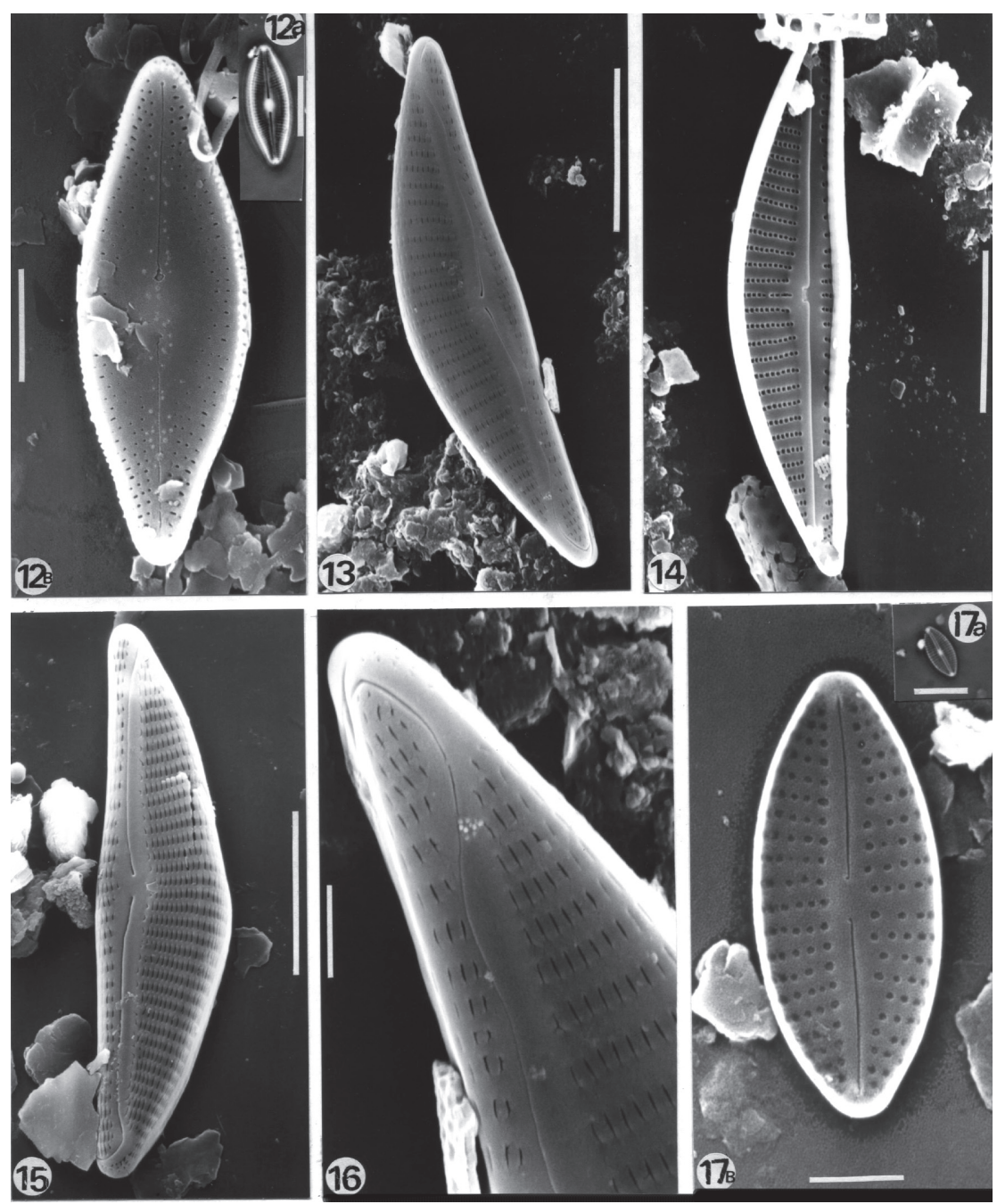

Fig. 12: Diadesmis confervaceae: Fig. 12A: LM, valve, Fig. 12B: SEM valve in external view. Fig. 13-14, 16: Encyonema jemtlandicum: SEM. Fig. 13: valve in external view, Fig. 14: valve in internal view. Fig. 15: Encyonema aff. jemtlandicum var. venezolana SEM: Fig. 15: valve in external view, Fig. 16: detail of the valve apex of the specimen ilustrated in Fig.13. Fig. 17: Eolimna subminuscula, Fig. 17A: LM, valve, Fig. 17B: SEM, valve in internal view. Scale bars= $2 \mu \mathrm{m}$ (Fig. 16, 17B); $5 \mu \mathrm{m}$ (Fig. 12B) and $10 \mu \mathrm{m}$ (Fig. 12A, 13, 14, 15, 17A).

(poles); ventral striae: 10 in $10 \mu \mathrm{m}$ (center), 11 in $10 \mu \mathrm{m}$ (poles); areolae: 32 in $10 \mu \mathrm{m}$.

Studied material: LPC 10007, 10017.

Ecological data: altitude: 1060 masl; conductivity: $61.2-126.2 \mu \mathrm{S} . \mathrm{cm}^{-1} ; \mathrm{T}^{\mathrm{o}} \mathrm{w}: 19.0-26.3^{\circ} \mathrm{C}$; pH: 6.2-7.6; dissolved oxygen: 5.0-8.6 $\mathrm{mgl}^{-1}$.

Distribution in Colombia: this species, only reported at the Andes of Venezuela and
Chile, is mentioned for the first time in the country.

Observations: The studied materials are similar in valve outline and dimensions to the material showed in Krammer (1997): 166, Fig. 14 but as in the literature there are not details of the fine morphology it is difficult to identify it without doubts. 
Eolimna subminuscula (Manguin)

Lange-Bertalot (Fig. 17A, B, 18)

G. Moser, Lange-Bertalot et Metzeltin 1998, Bibl. Diat. 38, p. 154.

Bas.: Navicula subminuscula Manguin

Valves lanceolate with subrostrate or subacute ends. Axial area linear, moderately wide. Central area variable, absent in some specimens and asymmetric due to the shortening of the median striae. Striae uniseriate composed of circular areolae, radiate at the poles and parallel at the center. Raphe filiform slightly arcuate, external proximal ends, dilated in small pores, gently curved to the same side and opposite to the distal hooked endings; internal proximal raphe ends slightly curved in the same direction and terminal ones with small helictoglossae. Length: 9.0-10.5 $\mu \mathrm{m}$, width: 4.0-4.5 $\mu \mathrm{m}$; striae: $16-22$ in $10 \mu \mathrm{m}$; areolae: $31-38$ in $10 \mu \mathrm{m}$.

Studied material: LPC 10006, 10016, 10020.

Ecological data: altitude: 400-1 100 masl.; conductivity: $126.2-256.0 \mu \mathrm{Scm}^{-1} ; \mathrm{T}^{\mathrm{o}} \mathrm{w}: 23.2-$ $30.0^{\circ} \mathrm{C}$; $\mathrm{pH}$ : 6.0-9.2; dissolved oxygen: 5.5-7.8 $\mathrm{mgl}^{-1}$.

Distribution in Colombia: this species, mentioned in the literature as cosmopolitan, is recorded in Colombia for the first time.

\section{Eolimna sp. aff. N. tantula Hustedt (Fig. 19)}

Hustedt in A. Schmidt's 1934 Atlas der Diatomaceen-Kunde: pl. 400, Fig. 54-57.

Valves linear-elliptical with rounded ends. Axial area linear-lanceolate, central area broad, semi-rectangular with short striae. Striae uniseriate, strongly radiate and curved; areolae punctate. Raphe filiform; external proximal ends dilated, internally gently curved to the same side; helictoglossae small. Length: 9-11 $\mu \mathrm{m}$, width: $3.0-3.5 \mu \mathrm{m}$; striae: $22-28$ in $10 \mu \mathrm{m}$ at the center and $25-28$ in $10 \mu \mathrm{m}$ at the ends; areolae: $56.0-66.5$ in $10 \mu \mathrm{m}$.

Studied material: LPC 10001, 10003.
Distribution in Colombia: this taxon is recorded in Colombia for the first time.

Observations: although the analyzed specimens belong to sites ecologically heterogeneous, they present little morphological variation. The valve outline, dimension, type of raphe and typo of striae evidences that the studied material belongs to the genus Eolimna but it could not be assigned to any species of the genus. It coincides in valve outline, dimensions and striae density with the specimens illustrated in Simonsen (1987) as the holotype of $N$. tantula Hustedt (Plate 275, Fig. 20 a 26), but the general appearance of these materials differ from the specimens illustrated by Hustedt (in Schmidt et al. 1934, Taf. 394-400) and in Hustedt (1962) under this name. Simonsen (1987) pointed out that $N$. tantula was reported without description in Hustedt (1934) and then described in Hustedt (1937) as Stauroneis fonticola. Also, this author recommends consulting Hustedt (1962). Our material do not coincide with any of the specimens illustrated by Hustedt in the above mentioned publications and are similar to Stauroneis fonticola in valve outline, morphometric data and the striae in the central area but differ in the presence of the conspicuous stauro. Our material also differs from the specimens described in Krammer and Lange-Bertalot (1986, pl. 76, Fig. 39-47) who pointed out that $N$. tantula is synonym of Navicula minima Grunow and that their Fig. 47 corresponds to the holotype of N. tantula. Comparing our materials with others in the literature we found that they are similar in valve morphology and morphometric data to those collected in Ecuador and illustrated as Eolimna (nov.?) spec. and Eolimna aff. minima (Grunow) Lange-Bertalot by Rumrich et al. (2000, Pl. 71, Fig. 5-8 and 4, 9 and 10 respectively) and to the specimens illustrated as $E$. sp. aff. minima in Monnier et al. (2003). On the basis of all above mentioned we believe that before proposing any new taxon or new combination it is necessary a comparative study with electron microscope of all the materials studied by Hustedt as $N$. tantula and S. fonticola and type material of $N$. minima. 

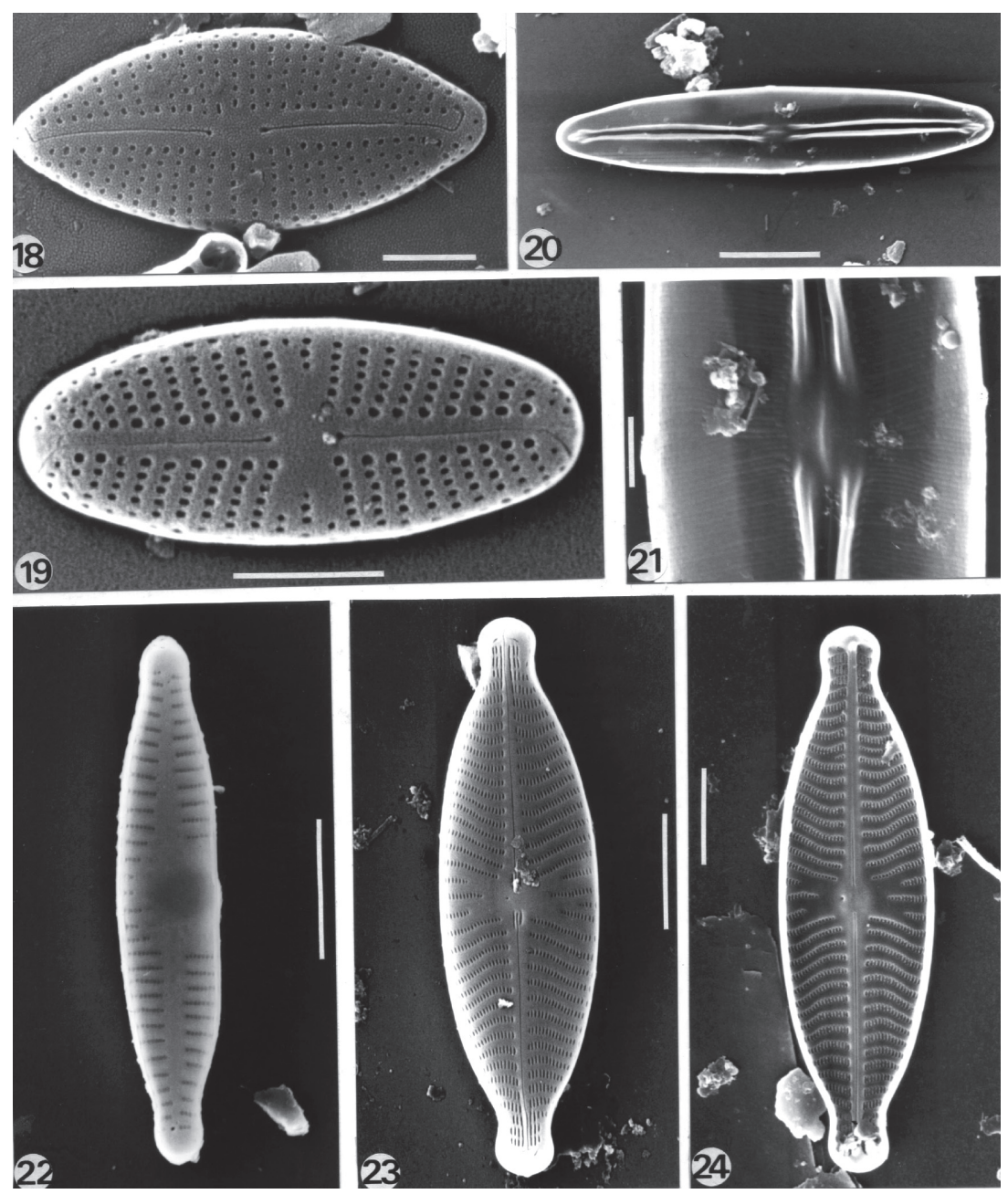

Fig. 18: Eolimna subminuscula, SEM: valve in external view. Fig. 19: Eolimna sp. aff. N. tantula, SEM: valve in external view. Fig. 20-21: Frustulia vulgaris, SEM, Fig. 20: valve in internal view, Fig. 21: detail of the valve centre. Fig. 22: Fragilaria capucina, SEM: valve in external view. Fig. 23-24: Geissleria decussis, SEM, Fig. 23: valve in external view, Fig. 24: valve in internal view. Scale bars $=1 \mu \mathrm{m}$ (Fig. 21), $2 \mu \mathrm{m}$ (Fig. 18, 19); $5 \mu \mathrm{m}$ (Fig. 20, 22, 23, 24).

\section{Fragilaria capucina}

Desmazieres (Fig. 22)

Desmazieres 1825: Plant. Cryp. Fr., Fasc. $10 \mathrm{~N}^{\circ} 453$

Valves linear to linear-elliptical with rounded to capitate ends. Axial area widening to the central part of the valve; central area asymmetric reaching one of the valve sides, inflated in some specimens. Striae uniseriate, parallel and slightly radiate to the poles. Rimoportulae eccentric, placed at one pole near the last stria.
No spines in the valve face and mantle junction. Length: 18-26 $\mu \mathrm{m}$; width: 3.5-4.5 $\mu \mathrm{m}$; striae: $15-16$ in $10 \mu \mathrm{m}$ at the center and 14 in 10 $\mu \mathrm{m}$ at the ends; areolae: $49-66$ in $10 \mu \mathrm{m}$.

Studied material: LPC 10012, 10019.

Ecological data: altitude: 840-1 100 masl; conductivity: $126.2-172.0 \mu \mathrm{Scm}^{-1} ; \mathrm{T}^{\mathrm{o}} \mathrm{W}$ : 23.0-23.2 ${ }^{\circ} \mathrm{C}$; $\mathrm{pH}$ : 5.8-7.6; dissolved oxygen: 4.7-6.5 $\mathrm{mgl}^{-1}$.

Distribution in Colombia: this cosmopolitan species is recorded for the first time. 
Observations: Williams and Round (1987) consider that Fragilaria vaucheriae (Kützing) Petersen is a different species and not a variety of $F$. capucina. Nevertheless in the studied populations we found a continious variation of the central area, some specimens with one side inflated and others without inflation. As they do not differ in the other characters we consider that all of them belong to F. capucina . This material resembles those described in Argentina (Sala, 1996) in the absence of marginal spines.

\section{Frustulia vulgaris (Thwaites)}

De Toni (Fig. 20-21)

De Toni 1891, Syllog. Alg. 2: 280

Bas. Schizonema vulgare Thwaites

Valves lanceolate to linear-lanceolate, ends rounded and slightly subrostrate. Raphe branches distinctly curved, accompanied by internal axial ribs which are interrupted at the central area. In internal view the central nodule and the helictoglossae are isolated from the axial ribs. External proximal and distal raphe endings Y-shaped. Axial area narrow; central area orbicular. Striae around the central area moderately but without exception distinctly radiate, circumradiate at the poles. Areolae somewhat irregularly spaced not forming straight apical lines. Length: 22-46 $\mu \mathrm{m}$; width: 4.5-4.7 $\mu \mathrm{m}$; striae: $22-35$ in $10 \mu \mathrm{m}$; areolae: 44 in $10 \mu \mathrm{m}$.

Studied material: LPC 10001, 10019.

Ecological data: altitude: 840-1 100 masl; conductivity: $61.2-172.0 \mu \mathrm{Scm}^{-1} ; \mathrm{T}^{\mathrm{o}} \mathrm{w}: 23.0-$ $26.3{ }^{\circ} \mathrm{C}$; $\mathrm{pH}$ : 5.8-7.6; dissolved oxygen: 4.7-8.0 $\mathrm{mgl}^{-1}$.

Distribution in Colombia: this cosmopolitan species was recorded in Tierras Bajas.

Observations: the studied material coincides with the description of the species given in Lange-Bertalot (2001).

Geissleria decussis (Østrup)
Lange-Bertalot (Fig. 23-24)

Lange-Bertalot and Metzeltin 1996, Iconogr. Diatomol. 2: 65.

\section{Bas. Navicula decussis Østrup}

Valves linear-elliptical with subcapitate ends. Axial area narrow and straight; central area transapically expanded with alternating short and long striae. Stigma, poroid, near the central nodule. Raphe filiform, straight, external proximal ends slightly dilated with two short ribs and distal ones curved to opposite sides. Internal proximal ends straight; helictoglossae small. Striae uniseriate and curved, radiate nearly all along the valve and gently convergent or parallel at the ends. Length: 22-23 $\mu \mathrm{m}$, width: $6.5-11.0 \mu \mathrm{m}$; striae: $14-17$ in $10 \mu \mathrm{m}$; areolae: $61-67$ in $10 \mu \mathrm{m}$.

Studied material: LPC 10003, 10018, 10019, 10020.

Ecological data: altitude: 400-1 100 masl; conductivity: $61.2-213.0 \mu \mathrm{Scm}^{-1} ; \mathrm{T}^{\mathrm{o}} \mathrm{w}: 23.2-$ $30.0^{\circ} \mathrm{C}$; $\mathrm{pH}$ : 5.5-8.1; dissolved oxygen: 4.7-8.0 $\mathrm{mgl}^{-1}$.

Distribution in Colombia: this cosmopolitan species is recorded for the first time in Colombia.

\section{Gomphonema clavatum}

Ehrenberg (Fig. 28-30)

Ehrenberg 1832 sensu Krammer and Lange Bertalot 1986: 367, Fig. 163: 4.

Valve heteropolar, clavate with rounded ends. Axial area linear gently widened to the valve center. Central area with the median striae shortened, stigma with circular external foramen, internally elongated, placed at the central nodule. Striae uniseriate, radiate throughout the valve; areolae with c-shaped foramina. Raphe lateral with the external fissures undulated; proximal ends dilated and distal ones irregular, turned to the same side; internal raphe fissures straight with hooked proximal ends and conspicuous helictoglossae. In some specimens the striae occupy the place of the apical pore field. Length: 27.5-38.0 $\mu \mathrm{m}$; width: $6.5-7.0 \mu \mathrm{m}$; striae: $10-11$ in $10 \mu \mathrm{m}$ at the center, 10-14 in $10 \mu \mathrm{m}$ at the head- pole and $12-14$ in $10 \mu \mathrm{m}$ at the foot- pole; areolae: 28-38 in $10 \mu \mathrm{m}$.

Studied material: LPC 10002, 10013, 10017. 
Ecological data: altitude: $1060-3250$ masl; conductivity: $23.0-126.2 \mu \mathrm{Scm}^{-1}$; $\mathrm{T}^{\mathrm{o}} \mathrm{w}$ : 11.0-26.3 ${ }^{\circ} \mathrm{C}$; $\mathrm{pH}$ : 6.2- 7.7; dissolved oxygen: 6.5- $8.6 \mathrm{mgl}^{-1}$.

Distribution in Colombia: this species was recorded in the Provincia de Alta Montaña.

\section{Gomphonema lagenula \\ Kützing (Fig. 25-27)}

Kützing 1844, Bacill.: 85, pl. 30, Fig. 60. Valves heteropolar, ovate to clavate with subcapitate ends. Axial area straight; central area delimited by the shortening of one median
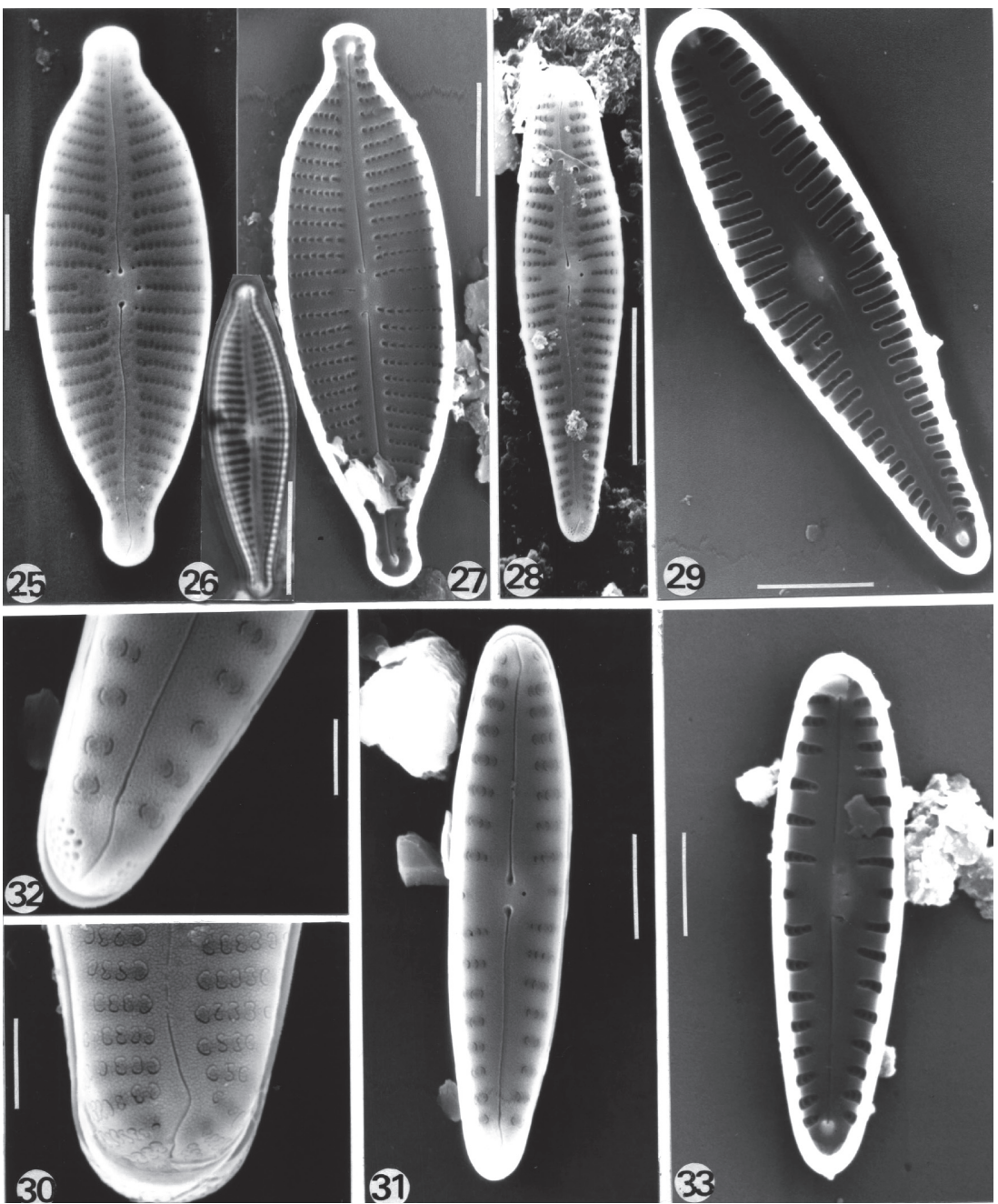

Fig. 25-27: Gomphonema lagenula, Fig. 25: SEM, valve in external view, Fig. 26: LM, valve, Fig. 27: SEM, valve in internal view. Fig. 28-30: Gomphonema clavatum, SEM, Fig. 28: valve in external view, Fig. 29 valve in internal view, Fig. 30: detail of the head-pole. Fig. 31-33: Gomphonema pumilum, SEM: Fig. 31: valve in external view, Fig. 32: detail of the foot-pole, Fig. 33: valve in internal view. Scale bars= $1 \mu \mathrm{m}$ (Fig. 32); $2 \mu \mathrm{m}$ (Fig. 30); $3 \mu \mathrm{m}$ (Fig. 31, 33); $5 \mu \mathrm{m}$ (Fig. 25, 27, 29); $10 \mu \mathrm{m}$ (Fig. 26, 28). 
stria. A stigma, placed at the central nodule at the end of the long central stria, has an external round opening and is internally elongated. Striae, uniseriate, slightly radiate at the center and radiate at the poles; areolae with c-shaped foramina. Raphe with external fissures slightly undulated, dilated proximal ends and distal ends bent to the same side; internally the raphe fissures are straight, with hooked proximal ends and conspicuous helictoglossae. Length: 24-31 $\mu \mathrm{m}$; width: 4-7.5 $\mu \mathrm{m}$; striae: $9-12$ in 10 $\mu \mathrm{m}$ at the center, $10-15$ in $10 \mu \mathrm{m}$ at the head pole; areolae: $30-39$ in $10 \mu \mathrm{m}$.

Studied material: LPC 10001, 10002, 10020.

Ecological data: altitude: 400-1 100 masl; conductivity: $126-213 \mu \mathrm{Scm}^{-1} ; \mathrm{T}^{\mathrm{o}} \mathrm{w}$ : $23.2-30.0$ ${ }^{\circ} \mathrm{C}$; pH 5.5- 8.1; dissolved oxygen: 7.1- 7.9 $\mathrm{mgl}^{-1}$.

Distribution in Colombia: this cosmopolitan species is recorded for the first time in the country.

\section{Gomphonema pumilum (Grunow) \\ Reichardt and Lange-Bertalot (Fig. 31-33)}

Reichardt and Lange-Bertalot. 1991, Nova Hedwigia 53: 528.

Valves heteropolar, lanceolate with rounded ends. Axial area lanceolate; central area symmetric with very short median striae; stigma externally circular and internally elongated, placed on the central nodule. Striae uniseriate, short, gently curved and slightly radiate; composed of areolae with external c-shaped foramina. Raphe nearly straight, external proximal ends dilated and distal ends bent to the same side; internal proximal ends bent in the same direction forming acute angles and then hooked; helictoglossae small. Apical pore fields small. Length: 10.5-22.5 $\mu \mathrm{m}$, width: 3-4 $\mu \mathrm{m}$; striae: $11-13$ in $10 \mu \mathrm{m}$; areolae: $45-50$ in $10 \mu \mathrm{m}$.

Studied material: LPC 10001, 10012, 10016, 10019.

Ecological data: altitude: 840-1 100 masl; conductivity: $126.2-256.0 \mu \mathrm{Scm}^{-1} ; \mathrm{T}^{\mathrm{o}} \mathrm{W}$ : 23-24 ${ }^{\circ} \mathrm{C}$; pH: 5.8-9.2; dissolved oxygen: 5.3$7.2 \mathrm{mgl}^{-1}$.
Distribution in Colombia: this cosmopolitan species is recorded for the first time in the country.

Observations: our material coincide with those described in Reichardt (1997: 103).

\section{Gomphonema punae}

Lange-Bertalot and Rumrich (Fig. 34-36)

Lange-Bertalot and Rumrich in Rumrich et al. 2000. Iconogr. Diatomol. 9: 140, pl. 129: Fig. 1-14.

Valves heteropolar, ovate with subrostrate ends. Axial area straight; central area asymmetric, delimited by the shortening of one of the central striae; stigma with an external circular opening and internally elongated, placed near one of the central striae. Striae uniseriate, parallel to slightly radiate; areolae with external irregular c-shaped foramina. Raphe gently undulated with external proximal ends slightly dilated and terminal ones bent to the same side; internal proximal ends hooked in the same direction, helictoglossae conspicuous. Apical pore-fields composed of 6 rows of round pores diagonally arranged. Length: $13-21 \mu \mathrm{m}$; width: 4.5-5.0 $\mu \mathrm{m}$; striae: $11-16$ in $10 \mu \mathrm{m}$; areolae: $40-42$ in $10 \mu \mathrm{m}$.

Studied material: LPC 10011, 10012, 10013, 10019.

Ecological data: altitude: 840-3 250 masl; conductivity: $23-172 \mu \mathrm{Scm}^{-1} ; \mathrm{T}^{\mathrm{o}} \mathrm{w}$ : $11.0-26.3$ ${ }^{\circ} \mathrm{C}$; $\mathrm{pH}$ : 6.3-7.6; dissolved oxygen: 4.7-8.0 mg. $1^{-1}$.

Distribution in Colombia: this taxon, recorded for the first time in Colombia, was only found in Chile (Rumrich et al., 2000).

\section{Sellaphora pupula (Kützing) \\ Mereschkowsky (Fig. 40-42)}

Mereschkowsky 1902, Ann. Mag. Nat. Hist. 2nd Ser. 7/9:187.

Bas.: Navicula pupula Kützing

Valves linear to elliptical-lanceolate with wide rounded ends, slightly protracted to subcapitate. Raphe straight, filiform, external proximal ends gently dilated and curved to the same 

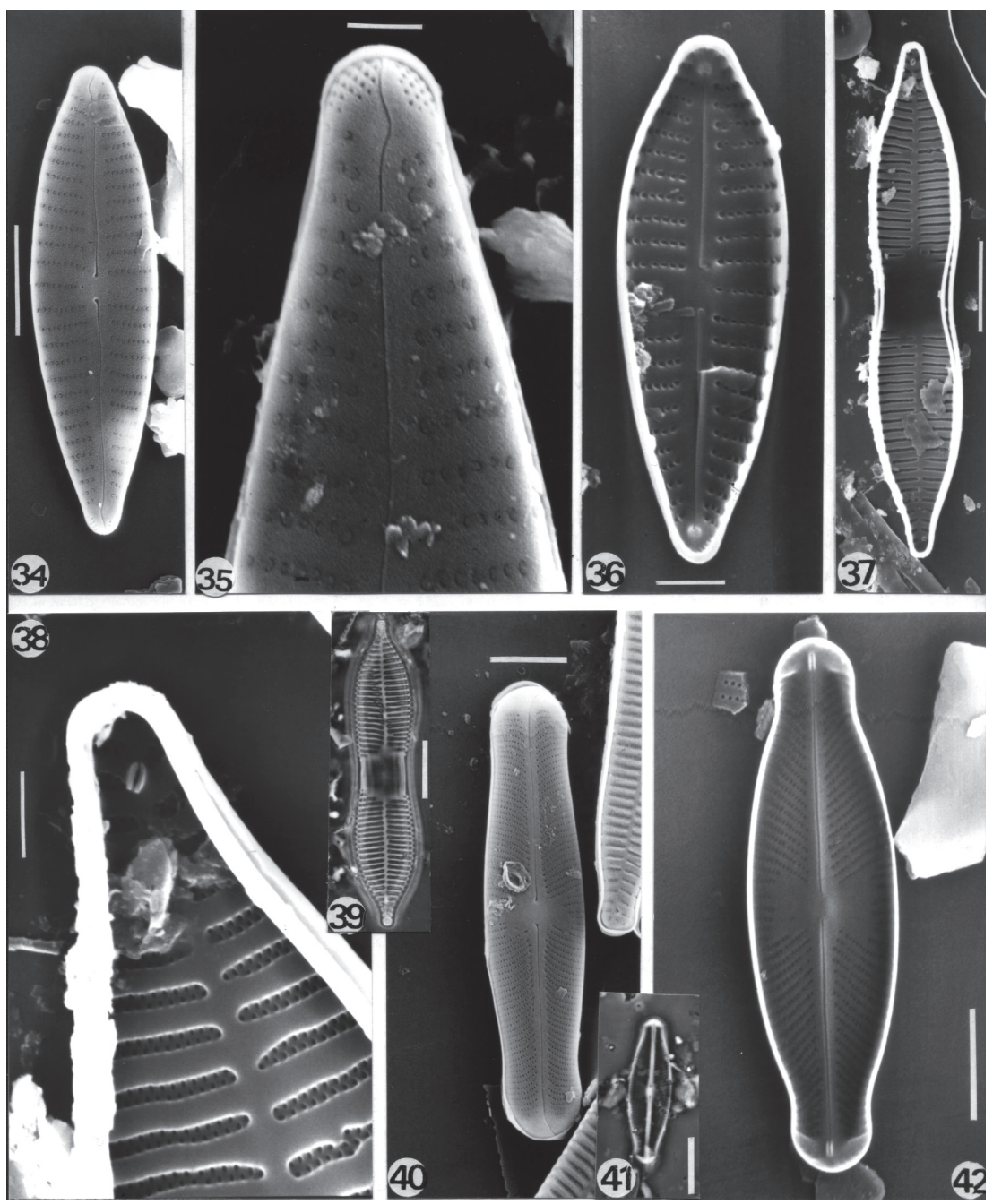

Fig. 34-36: Gomphonema punae SEM, Fig. 34 Valve in external view, Fig. 35: detail of the foot-pole, Fig. 36: Valve in internal view. Fig. 37-39: Synedra goulardi: Fig 37: SEM, valve in internal view, Fig. 38: detail of the apex, Fig. 39: LM, valve. Fig. 40-42: Sellaphora pupula, Fig. 40: SEM, valve in external view; Fig. 41: LM, valve; Fig. 42: SEM, valve in internal view. Scale bars $=1 \mu \mathrm{m}$ (Fig. 35); $2 \mu \mathrm{m}$ (Fig. 36, 38); $5 \mu \mathrm{m}$ (Fig. 34, 40, 42); $10 \mu \mathrm{m}$ (Fig. 37, 39, 41).

side, distal fissures hooked on the same direction but opposite to central ones; internal central endings hardly twisted to the same side; helictoglossae axially positioned over the conspicuous terminal nodules, laterally expanded. Axial area linear and narrow, internally swelled, visible even with LM; central area laterally expanded. Striae uniseriate, strongly radiate and undulated composed of small circular areolae. Length: 23.5-29 $\mu \mathrm{m}$, width: 6-7 $\mu \mathrm{m}$; striae: $20-25$ in 10 $\mu \mathrm{m}$ at the center and $18-30$ in $10 \mu \mathrm{m}$ at the ends; areolae: $49-56$ in $10 \mu \mathrm{m}$.

Studied material: LPC 10007, 10013, 10019, 10020.

Ecological data: altitude: 400-3 250 masl; conductivity: $23-176 \mu \mathrm{Scm}^{-1} ; \mathrm{T}^{\mathrm{o}} \mathrm{w}: 11-30{ }^{\circ} \mathrm{C}$; pH: 6.5-7.7; dissolved oxygen: 4.7-8.0 $\mathrm{mgl}^{-1}$.

Distribution in Colombia: this species was registered in the Provincias Andina and Alta Montaña. 
Observations: the striae density of the studied specimens coincides with those described in Germain (1981) and differs from those in Patrick and Reimer (1966).

\section{Synedra goulardi}

Brébisson ex Cleve and Grunow (Fig. 37-39)

Cleve and Grunow 1880, Kong. Svensk. Vetensk.-Akad. Hand., 17: 107.

Valves linear-lanceolate, constricted at the middle, with rostrate ends. Axial area narrow and straight; central area rectangular, reaching the margins. Striae biseriate, parallel or slightly radiate; areolae circular, small, arranged in quincunx. One rimoportula at each pole in variable position. Length: $52.5-80.0 \mu \mathrm{m}$; width: 8-16 $\mu \mathrm{m}$; striae: 9-11 in $10 \mu \mathrm{m}$; areolae: 41-84 in $10 \mu \mathrm{m}$.

Studied material: LPC 10003, 10019.

Ecological data: altitude: 400-1 100 masl; conductivity: $61-176 \mu \mathrm{Scm}^{-1} ; \mathrm{T}^{\mathrm{o}} \mathrm{w}: 26.3-30.0$ ${ }^{\circ} \mathrm{C}$; $\mathrm{pH}$ : 6.5-7.4; dissolved oxygen: 7.1-8.0 $\mathrm{mgl}^{-1}$.

Distribution in Colombia: this pantropical species was reported in the Provincia Costera.

Observations: our material coincides in the ultrastructure with the material described in Williams (1986). According to Compère (2001) this species should be transferreded to the genus Ulnaria (Kützing) Compère but as our specimens differ in valve outline from the lectotype illustrated in Lange-Bertalot (1980), we pospone this proposal of transference until the type material is analysed with electron microscopy.

\section{Ulnaria lanceolata}

(Kützing) Compère (Fig. 45-48)

Compère 2001, Stud. on Diat. ded. Prof. Lange-Bertalot: 10

Bas.: Synedra lanceolata Kützing

Valves linear, sometimes narrowed at valve center, with rostrate or subcapitate ends. Axial area narrow; central area rectangular unilateral in some specimens. Striae biseriate, parallel, slightly radiate at the poles; sunken in the internal side of the valve. Areolae circular and small, arranged in quincunx. One rimoportula at each pole with a prominent internal labium diagonally positioned. Apical pore fields well developed. Length: $81-117 \mu \mathrm{m}$; width: $6.5-10 \mu \mathrm{m}$; striae: $10-11$ in $10 \mu \mathrm{m}$; areolae: $41-72$ in $10 \mu \mathrm{m}$.

Studied material: LPC 10001, 10017, 10020.

Ecological data: altitude: 400-1 100 masl; conductivity: $61.2-126.2 \mu \mathrm{Scm}^{-1} ; \mathrm{T}^{\mathrm{o}} \mathrm{w}: 23.2-$ $26.3{ }^{\circ} \mathrm{C}$; $\mathrm{pH}$ : 7.3-7.6; dissolved oxygen: 6.5 $8.0 \mathrm{mgl}^{-1}$.

Distribution in Colombia: this pantropical species is recorded in the country for the first time.

\section{Ulnaria ulna \\ (Nitzsch) Compère (Fig. 43-44)}

Compère 2001, Stud. on Diat. ded. Prof. Lange-Bertalot :100

Bas. Bacillaria ulna Nitzsch

Valves linear with rostrate ends. Axial area narrow; central area rectangular with short striae at the margins or absent. Striae uniseriate, parallel, slightly radiate at the poles. One rimoportula at each pole at the end of one of the last striae. Apical pore fields well developed with two spines at the upper side.

Length: 117-217 $\mu \mathrm{m}$, width: 4.5-7.8 $\mu \mathrm{m}$; striae: $9-10$ in $10 \mu \mathrm{m}$; areolae: 38 in $10 \mu \mathrm{m}$.

Studied material: LPC 10001, 10017.

Ecological data: altitude: 1060-1 100 masl; conductivity: $61.2-126.2 \mu \mathrm{Scm}^{-1} ; \mathrm{T}^{\mathrm{o}} \mathrm{W}$ : 19.0-26.3 ${ }^{\circ} \mathrm{C}$; $\mathrm{pH}$ : 6.2-7.6; dissolved oxygen: 6.5-8.6 $\mathrm{mgl}^{-1}$.

Distribution in Colombia: this cosmopolitan species has a wide distribution in Colombia, it was recorded in the Provinces of Alta Montaña, Andina, Tierras Bajas and Costera.

\section{DISCUSSION}

Comparing the inventories of preliminary studies held in lentic and lotic systems, 90 diatom taxa were identified from Antioquia and 

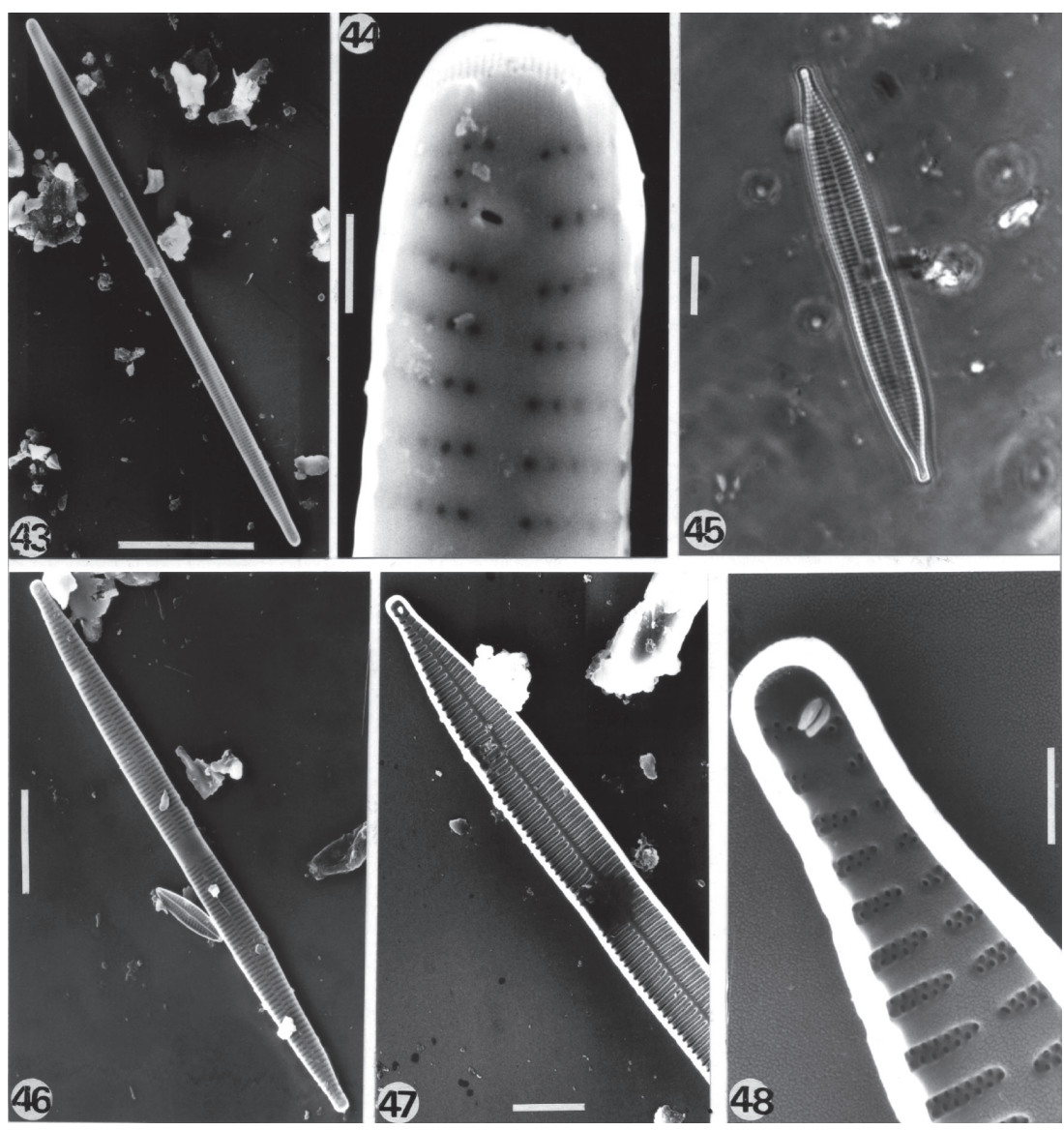

Fig. 43-44: Ulnaria ulna, SEM, Fig. 43: valve in external view, Fig. 44: detail of an apex. Fig. 45-48: Ulnaria lanceolata. Fig. 45: LM, valve, Fig. 46: SEM, valve in external view, Fig. 47: SEM, detail of a valve in internal view, Fig. 48: SEM, detail of an apex. Scale bars= $2 \mu \mathrm{m}$ (Fig. 44, 48); $10 \mu \mathrm{m}$ (Fig. 45, 47); $20 \mu \mathrm{m}$ (Fig. 46); $30 \mu \mathrm{m}$ (Fig. 43).

Chocó Departments and 116 from Santander. Although the studied sites belong to the Colombian Andean region only 23 taxa were common to these three departments. These taxa belong to the orders Thalassiosirales (1), Aulacoseirales (1), Fragilariales (4), Cymbellales (7), Achnanthales (2), Naviculales (7), and Thalassiophysales (1).

From the species analised in this paper $A$. montana, C. aff. bacillum, C. affinis, E. aff. jemtlandicum var. venezolana, E. subminuscula, Eolimna sp. aff. N. tantula, F. capucina, $G$. decussis, G. clavatum, G. lagenula, $G$. pumilum, G. punae and U. lanceolata are reported for the first time in Colombia and $E$. jemtlandicum is here reported for the first time in South America. A. granulata, C. meneghiniana and $U$. ulna have a wide distribution in the country while C. placentula var. euglypta was recorded only in the Provincia de Alta Montaña, S. pupula in Río Medellín, F. vulgaris in Tierras Bajas and $S$. goulardi in Provincia Costera. The majority of the reports were obtained from ecological studies so it is difficult to corroborate or reject the distribution of these taxa in the country. We compared our results with the taxonomic analysis held in the Colombian Amazonia with SEM (Sala et al. 1999, 2002a, 2002b). This comparison shows that although both areas are in the equatorial 
region, only $A$. granulata, $C$. meneghiniana and $D$. confervacea were represented at these areas. This difference in the diatom floras of low and highlands at the Ecuador and Tropics reflect the influence of altitude in climatic characteristics. Our observations are coincident with those of Metzeltin and Lange-Bertalot (1998) and Rumrich et al. (2000) when studying the South American diatom flora.

On the other hand, the great majority of the analyzed taxa are mentioned in the literature as cosmopolitan with the exception of $U$. lanceolata and $S$. goulardi that have a pantropical distribution and Encyonema aff. jemtlandicum var. venezolana and G. punae found only in South America.

The comparison of the fine valve morphology of the studied materials and their descriptions in the literature, even in the case of taxa described in temperate or cold regions, showed that there are not important differences with the exception of $C$. aff. bacillum, E. jemtlandicum aff. var. venezolana and Eolimna sp. aff. $N$. tantula that need more detailed analyses.

\section{ACKNOWLEDGMENTS}

To the Institute of Biología of Universidad de Antioquia, to Colciencias, and to Red Latinomericana de Botánica (RLB) for the fellowships given to the second and third authors respectively.

\section{RESUMEN}

En este artículo se analizan con microscopios de luz y electrónico de barrido 23 taxones de diatomeas provenientes de sistemas lénticos y lóticos andinos localizados en los Departamentos de Antioquia, Santander y Chocó, Colombia. Cada taxon es descrito e ilustrado y se brinda información acerca de su distribución en Colombia y de las condiciones físicas y químicas en las que fueron colectados. Los taxones estudiados pertenecen a los órdenes Thalassiosirales (1), Aulacoseirales (1), Fragilariales (4), Cymbellales (7), Achnanthales (2), Naviculales (7) y Thalassiophysales (1). 15 de ellos son registrados por primera vez para Colombia y Encyonema jemtlandicum es primer registro para América del Sur. Una comparación con la flora diatomológica de la Amazonía Colombiana, mostró que únicamente 3 taxones fueron hallados en ambas regiones, probablemente debido a la influencia de los gradientes altitudinales.

Palabras clave: diatomeas, taxonomía, cuerpos de agua continentales, trópicos, Colombia, región andina.

\section{REFERENCES}

Anonymous. 1975. Proposals for standardization of diatom terminology and diagnoses. Nova Hedw. 53: 232-354.

Asprilla, S., J.J. Ramírez \& G. Roldan. 1998. Caracterización limnológica de la ciénaga de Joutaudó (Chocó, Colombia). Actual. Biol. 20: 87-107.

Barber, H.G. \& E.Y. Haworth. 1981. A guide to the morphology of the diatom frustule. Freshwater Biological Association 44, Ambleside, England.

Corporación Autónoma Regional para la Defensa de la Meseta de Bucaramanga (CDMB). 2004. Plan de acción trienal 2004-2006. Bucaramanga, Colombia.

CEN/TC 230, prEN 13946. 2002. Water quality-Guidance standard for the routine sampling and pretreatment of benthic diatoms from rivers. 14 p. (www.techind.fi/ standard/uutiset/tilaajat/sfs_en_12952-6.pdf)

Compère, P. 2001. Ulnaria (Kützing) Compère, a new genus name for Fragilaria subgen Alterasynedra Lange-Bertalot with comments on the typification of Synedra Ehrenberg, p 97-101. In R. Jahn, P. Kociolek, A. Witkowski \& P. Compère (eds.). Studies on Diatoms. dedicated to Prof. Dr. Dr. HC Horst Lange-Bertalot on the occasion of his $65^{\text {th }}$ Birthday. Gantner, Ruggell, Germany.

Donato, J.C., L.E. González \& C.L. Rodríguez. 1996. Ecología de dos sistemas acuáticos de Páramo. Acad. Colomb. Cienc. Exac. Fis. Nat. Colección Javier Álvarez Lleras 9, Bogotá, Colombia.

Donato, J.C. 2001. Fitoplancton de los lagos andinos del norte de Sudamérica (Colombia). Composición y factores de distribución. Acad. Colomb. Cienc. Exac. Fis. Nat. Colección Javier Álvarez Lleras 19, Bogotá, Colombia.

Empresas Públicas de Medellín. 1988. Cuenca quebrada Piedras Blancas: estudio geomorfológico. Medellín, Colombia.

Espinal, L.S. 1992. Formaciones vegetales de Antioquia. Rev. Fac. Nac. Agron. 24: 60-67.

Germain, H. 1981. Flore des diatomées. Diatomophycées. Societé Nouvelle des Editions Boubée, Paris, France. 
Hernández-Atilano, E., N.J. Aguirre \& J. Palacio. 2005. Variación de la estructura de la comunidad de algas perifíticas en la microcuenca de la quebrada La Vega, municipio de San Roque (Antioquia), Colombia. Actual. Biol. 27: 67-77.

Hustedt, F. 1934. Die Diatomeenflora von Poggenphols Moor bei Dötlingen in Oldenburg. Abhandlungen und Vortr. Bremer Wissenschaften Gesner 8/9: 362- 403.

Hustedt, F. 1937. Systematische und ökologische Untersuchungen über die Diatomeen-Flora von Java, Bali und Sumatra nach dem Material der Deutschen Limnologischen Sunda-Expedition. Teil I. Systematischer Teil, Forsetzung. Arch. Hydrobiol. Suppl. 15: 187-295.

Hustedt, F. 1962. Die Kieselalgen Deutschlands, Österreichs und der Schweiz. Dr. L. Rabenhorst Kryptogamenflora von Deutschlan, Österreich und der Schweiz, Leipzig: Akademische Verlagsgesellschaft 7 (Teil 3; Lief. 2): 161-348.

Kociolek, P. \& S. Spaulding. 2000. Freshwater Diatom Biography. Nova Hedw. 71: 1-19.

Krammer, K. 1997. Die cymbelloiden Diatomeen. Eine Monographie der weltweit bekannten taxa. Teil 1. Allgemeines und Encyonema Part. Bibliotheca Diatomologica. Band 36. J. Cramer, Berlin-Stuttgart, Germany.

Krammer, K. \& H. Lange Bertalot. 1986. Bacillariophyceae, In Süsswasserflora von Mittleuropa. Band 2, Teil 1. Naviculaceae. Gustav Fisher Verlag, Jena, Germany. 876 p.

Lange-Bertalot, H. 1980. Zur systematischen Bewertung der bandförmigen Kolonien bei Navicula und Fragilaria. Nova Hedw. Band 33: 723-786.

Lange-Bertalot, H. 2001. Diatoms of Europe. Diatoms of the European Inland Waters and Comparable Habitats. Navicula sensu stricto 10 Genera separated from Navicula sensu lato Frustulia. A.R.G. Gantner K.G., Ruggel, Germany.

Lange-Bertalot, H. \& G. Moser. 1994. Brachysira. Monographie der Gattung. Wichtige Indikator-Species für das Gewässer- Monitoring und Naviculadicta nov. gen. Bibliotheca Diatomologica Band 29. J. Cramer, Berlin-Stuttgart, Germany.

Lange-Bertalot, H., K. Külbs, T. Lauser, M. NörpelSchempp \& M. Willman. 1996. Diatom taxa introduced by Georg Krasske Documentation and Revision. Iconographia Diatomologica. Annotated Diatom Micrographs. Volume 3. Koeltz Scientific Books, Königstein, Germany.
Lozano, C.G., L.N. Parra, R.S. Moro \& J.J. Ramírez. 1999. Inferencias paleolimnológicas del Holoceno con base en diatomeas en la laguna Puente Largo, Páramo de Frontino, Antioquia, p. 57-116. In M.T. Flórez \& C.G. Lozano (eds.). Silicofósiles altoandinos. Colciencias, Universidad Nacional de Medellín, Comité de Investigaciones Universidad de Antioquia, Medellín, Colombia.

Metzeltin, D. \& H. Lange-Bertalot. 1998. Tropical Diatoms of South America I. Koeltz Scientific Books, Germany.

Metzeltin, D. \& H. Lange-Bertalot. 2007. Tropical Diatoms of South America II. A.R.G. Gantner, Germany.

Monnnier, O., H. Lange-Bertalot \& J. Bertrand. 2003. La Flore des diatomees d'un aquarium d'eau douce tropicale I. Observations taxonomiques. Actes du XXI Colloque de 1'Association des Diatomistes de Langue Française. Deuxième Supplément Hors Série Société des Sciences Naturelles de 1 'Ouest de la France: 125-165.

Montoya, Y. 1998. Estructura de la comunidad perifítica presente en dos estaciones muestreo en la zona de ritral del Río Medellín, Antioquia, Colombia. Trabajo de grado. Universidad de Antioquia, Medellín, Colombia.

Montoya, Y. 2005. Caracterización morfométrica básica de tres lagos someros en el municipio de El Carmen de Viboral (Antioquia), Colombia. Actual. Biol. 27 : 79-86.

Moreno, L.F. 1989. Colonización del perifiton en tres embalses del oriente antioqueño. Disertación de Maestría. Universidad de Antioquia, Medellín, Colombia.

Patrick, R. \& C.W. Reimer. 1966. The diatoms from the United States. Vol. II. Monogr. Acad. Nat. Sci., Philadelphia 13: 1-688.

Plata, Y. 2000. Distribución horizontal, biomasa y productividad primaria de la comunidad fitoplantónica de la ciénaga de Chucurí (Santander, Colombia). Trabajo de grado. Universidad Industrial de Santander, Bucaramanga, Colombia.

Ramírez, J.J. 1994. Dinámica poblacional de dos especies de Anabaenopsis (Wolosz.) V. Mill. 1923 en una laguna eutrófica tropical. Rev. Hidrobiol. Trop. 27: 337-346.

Ramírez, J.J. \& A. Díaz. 1994. Caracterización limnológica y estructura de la comunidad fitoplanctónica en la laguna del Parque Norte, Medellín, Colombia. Hoehnea 21: 7-28. 
Ramírez, J.J. \& T. Machado. 1982. Influencia de la precipitación y los ortofosfatos en el fitoplancton de la represa La Fé. Actual. Biol. 11: 3-21.

Ramírez, J.J., C.E Bicudo; G. Roldán \& L.C. García. 2000. Temporal and vertical variations on the phytoplankton community structure and its relation with some morphometric factors in four colombian reservoirs. Caldasia 22: 108-126.

Reichardt, E. 1997. Taxonomische Revision des Artenkomplexes um Gomphonema pumilum (Bacillariophyceae). Nova Hedw. 65: 99-129.

Ross, R., E.J. Cox, D.G. Karayeva, D.G. Mann, T.B. Padock, R. Simonsen \& P.A. Sims. 1979. An emended terminology for the siliceous components of the diatom cell. Nov. Hedw. 64: 513-533.

Rumrich, U., H. Lange-Bertalot \& M. Rumrich. 2000 Diatomeen der Anden von Venezuela bis Patagonien/ Feuerland Und zwei weitere Beiträge. A.R.G. Gantner K.G., Germany.

Sala, S., S. Duque, M. Núñez \& A. Lamaro. 2002a Diatoms from the Colombian Amazonia. Cryptog. Algol. 23: 75-99.

Sala, S.E., S. Duque, M. Núñez \& A. Lamaro 2002b. Diatoms from the Colombian Amazon: some species of the genus Eunotia (Bacillariophyceae). Acta Amazon. 32: 589-603.
Sala, S.E., S. Duque, M. Nuñéz \& A. Lamaro. 1999. Nuevos registros de diatomeas (Bacillariophyceae) de la Amazonia Colombiana. Caldasia 21: 26-37.

Sala, S.E. 1996. Flora Diatomológica del Embalse Paso de las Piedras (Argentina) I: Fam. Diatomaceae, Fam. Achnanthaceae y Fam. Eunotiaceae (O. Pennales). Darwiniana 34: 251-266.

Schmitd, A., M. Schmidt, F. Fricke, H. Heiden, O. Müller \& H. Hustedt. 1934. Atlas der Diatomaceen Kunde, Heft 97-98, T. 385-392. R. Reisland, Leipzig.

Simonsen, R. 1987. Atlas and Catalogue of the Diatom Types of Friedrich Hustedt. J. Cramer, Berlin, Germany. Volume 1: 525 pp; Volume 2: 395 pl.

Williams, D.M. 1986. Comparative morphology of some species of Synedra Ehrenb. With a new definition of the genus. Diat. Res. 1: 131-152.

Williams, D.M. \& F.E. Round. 1987. Revision of the genus Fragilaria. Diatom Res. 2: 267-288.

\section{REFERENCIAS DE INTERNET}

Imani. 2003. Catálogo de poblaciones de algas dulceacuícolas registradas para Colombia. (Downloaded: April 1st, 2003, http://www.unal.edu.co/un/imani/algascloroph.htm). 